\title{
Increasing Stability of $\alpha$-amylase Obtained from Bacillus subtilis ITBCCB148 by Immobilization with Chitosan
}

\author{
Yandri ${ }^{1, *}$, Tati Suhartati ${ }^{1}$, Heri Satria ${ }^{1}$, Arum Widyasmara ${ }^{1,2}$ and Sutopo Hadi ${ }^{1, *}$ \\ ${ }^{1}$ Department of Chemistry, University of Lampung Bandar Lampung Indonesia 35145 \\ ${ }^{2}$ Present address: Senior Technique Industrial School. Bandar Lampung, Indonesia
}

\begin{abstract}
In this research, the immobilization of $\alpha$-amylase from Bacillus subtilis ITBCCB148 by crosslinking method on chitosan matrix has been performed. This research aims to know the effect of immobilization on the thermal stability of $\alpha$-amylase. The results showed that the native $\alpha$-amylase has an optimum temperature of $65^{\circ} \mathrm{C}$, $\mathrm{K}_{\mathrm{M}}=1.6 \mathrm{mg} \mathrm{mL}^{-1}$ substrate, and $\mathrm{V}_{\max }=39.7 \mu \mathrm{mol} \mathrm{mL}^{-1} \mathrm{~min}^{-1}$. The immobilized $\alpha$-amylase has optimum temperature of $75^{\circ} \mathrm{C}, \mathrm{K}_{\mathrm{M}}=3.5 \mathrm{mg} \mathrm{mL}^{-1}$ substrate, and $\mathrm{V}_{\max }=7.05 \mu \mathrm{mol} \mathrm{mL}^{-1} \mathrm{~min}^{-1}$. The residual activity of the native and immobilized enzyme on thermal stability test at $65^{\circ} \mathrm{C}$ for 80 minutes was $58 \%$ and $86.15 \%$, respectively. The immobilized enzyme can be reused up to six repeated cycles. The thermodynamic data of native enzyme was $\mathrm{t}_{1 / 2}=113.6 \mathrm{~min}, \mathrm{k}_{\mathrm{i}}=6.1 \times 10^{-3} \mathrm{~min}^{-1}$, and $\Delta \mathrm{G}_{\mathrm{i}}=107.3 \mathrm{~kJ} \mathrm{~mol}^{-1}$, while the immobilized enzyme was $\mathrm{t}_{1 / 2}=433.1 \mathrm{~min}$, $\mathrm{k}_{\mathrm{i}}=1.6 \times 10^{-3} \mathrm{~min}^{-1}$, and $\Delta \mathrm{G}_{\mathrm{i}} 111.1 \mathrm{~kJ} \mathrm{~mol}^{-1}$. Based on the decrease of $\mathrm{k}_{\mathrm{i}}$, and the increase of $\Delta \mathrm{G}_{\mathrm{i}}$ and half-life $\left(\mathrm{t}_{\mathrm{t} / 2}\right)$ values, the immobilization of $\alpha$-amylase with chitosan can increase the thermal stability of this enzyme.
\end{abstract}

Keywords: $\alpha$-amylase, $B$. subtilis ITBCCB148, chitosan, immobilization.

\section{Introdcution}

Amylase is an enzyme that can catalyze the degradation of amylum, glycogen and oligosaccharide randomly. This enzyme divided into 4 groups ${ }^{1}$ namely (i) exo amylase that break down the $\alpha-1,4$ glycosidic bond outside the molecule ( $\beta$-amylase is an example of this type); (ii) glucoamylase catalyzes the break down of $\alpha-1,4$ and $\alpha-1,6$ glycosidic bonds outside of the molecule; (iii) debranching enzyme that specifically catalyzes the breakdown of $\alpha-1,6$ glycosidic bond in amylum or amylopectin. (pululanase and isoamylase belong to this group); (iv) endo amylase that catalyzes the break down of amylum in the middle or inside of the molecule ${ }^{2}$, an example of this group is $\alpha$-amylase.

Microorganisms are the major sources of $\alpha$-amylase, mainly bacteria and fungi that lead to many industrial uses, and it has been widely studied due to relatively large application scale ${ }^{3}$. Bacterial $\alpha$-amylase having new characteristics have been the main focus on the current research ${ }^{4}$. B. subtilis is gram-positive rod-shaped bacteria, is able to form endospore, to stand in the hazard ecological environment from radiation, solvent, temperature and extreme $\mathrm{pH}^{5}$. Amylase degrading amylum is an important enzyme used in industrial process and donates high proportion on enzyme market ${ }^{6}$.
In food industries, amylum hydrolysis to produce the reduced sugar generally occur on batch reaction, where economically cause detrimental as the enzyme can only be used once. In order for the enzyme can be used repeatedly, enzyme immobilization has been applied in some industries. Nowadays, $\alpha$-amylase has been immobilized covalently on different matrices like microsphere poly-(hydroxyethylmethacrylate), poly(methylmethacrylate-acrylic acid) and zirconium membrane, $\alpha$-amylase has been used as general buffers such as nitrocellulose membrane and chitosan matrix physically and ion exchange adsoprtion ${ }^{7}$.

Immobilization process on $\alpha$-amylase from B.subtilis ITBCCB148 has successfully increased the enzyme stability at high temperature using diethylaminoethyl cellulose (DEAE-Cellulose) ${ }^{8}$; carboxymethyl cellulose (CM-Cellulose) ${ }^{9}$; and bentonite ${ }^{10,11}$, calcium alginate ${ }^{12}$ although the increase was only $1.5 ; 3.67$ and 2.12 , however, the immobilized enzymes could be used between 5-6 times. Immobilization on $\alpha$-amylase has also been performed using amberlite ${ }^{13}$ and gelatin ${ }^{14}$ where they have successfully increased the stability of this enzyme. 
Chitosan is a material that is able to be used for buffer enzyme or whole cell. Chitosan is a deacetylation product of chitin produced from the outer frame of crustacea family having better solubility in acidic solution than chitin.

Chitosan is also a cheap compound, inert, hydrophilic, biocompatible buffer thus it is interesting to be used for a buffer in immobilization of enzyme. The presence of ammine groups facilitates the covalent bond in the enzyme. Immobilization could be done through transparent chitosan film or by chitosan seed entrapment method ${ }^{15}$.

Based on the reported results, in this work, immobilization is chosen to increase the stability of $\alpha$-amylase from $B$. subtilis ITBCCB148 using the chitosan.

\section{Materials and method}

\subsection{Materials}

Microorganism used was bacteria of $B$. subtilis ITBCCB148 obtained from the Microbiology and Fermentation Technology Laboratory Bandung Institute of Technology. All materials used were chemical substances with pro analysis (pa) grade.

\subsection{Methods}

2.2.1. Isolation, purification and activity test of $\alpha$-amylase and protein content determination

The isolation and purification were conducted based on published methods 16,17 . The activity test of $\alpha$-amylase was performed with Fuwa method ${ }^{18}$ and Mandels 19 method. The protein content was determined by Lowry ${ }^{20}$ method.

\subsubsection{Immobilization of purified enzyme 2.2.2.1. Determination of optimum glutaraldehyde concentration}

To a centrifuge tube, chitosan powder $(0.25 \mathrm{~g})$ was placed and stabilized with $0.1 \mathrm{M}$ phosphate buffer, $\mathrm{pH}$ 6.5. The matrix was separated from the solution by centrifugation. To the matrix, $0.25 \mathrm{~mL}$ of dialyzed enzyme and different concentrations $(0.2$ to $1.0 \%)$ of $0.25 \mathrm{~mL}$ glutaraldehyde were added. The mixture was then mixed at $25^{\circ} \mathrm{C}$ for $30 \mathrm{~min}$ and was washed with the above buffer. It was then separated by centrifugation.

$0.25 \mathrm{~mL}$ filtrate was taken as a control for the Mandels test, and the remaining of the filtrate was discarded. The precipitate of enzyme chitosan mixture was added with the substrate of amylum $0.1 \% 0.5 \mathrm{~mL}$ and incubated at $60^{\circ} \mathrm{C}$ for $30 \mathrm{~min}$ and stirred for every $10 \mathrm{~min}$. The mixture was separated by centrifugation. $0.5 \mathrm{~mL}$ of filtrate was taken to the reaction tube and was added $1.0 \mathrm{~mL} 3,5-$ Dinitrosalicylate (DNS) reagent, and the activity test of the enzyme was performed using Mandel's method. The glutaraldehyde concentration giving the highest enzyme activity was set as optimum glutaraldehyde concentration ${ }^{21}$.

2.2.2.2. Determination of $\mathbf{p H}$ for optimal binding $0.25 \mathrm{~g}$ chitosan powder was placed in a centrifuge tube and stabilized with phosphate buffer $0.1 \mathrm{M}$ with $\mathrm{pH}$ variation of $5.0 ; 5.5 ; 6.0 ; 6.5 ; 7.0$ and 7.5 . The matrix was separated from the solution by centrifugation, then was added with $0.25 \mathrm{~mL}$ of dialyzed enzyme and $0.25 \mathrm{~mL}$ glutaraldehyde in optimum concentration. The mixture was mixed at room temperature for 30 minutes, washed with phosphate buffer $0.1 \mathrm{M}$ based on each $\mathrm{pH}$ variation and separated by centrifugation. The filtrate was pipetted $0.25 \mathrm{~mL}$ as test control on Mandels, and the remaining filtrate was removed. The precipitate of chitosan enzyme was added with amylum substrate $0.1 \% 0.5 \mathrm{~mL}$ and incubated at $60^{\circ} \mathrm{C}$ for 30 minutes and stirred for every 10 minutes. The mixture was then separated by centrifugation. $0.5 \mathrm{~mL}$ filtrate was taken and placed into a test tube, $1.0 \mathrm{~mL}$ of DNS reagent was added and the enzyme activity was tested using the Mandels method. The buffer $\mathrm{pH}$ at which the highest enzyme activity is determined as the optimum $\mathrm{pH}$.

\subsubsection{Characterization of native and immobilized $\alpha$-amylase}

2.2.3.1. Determination of optimum temperature of native and immobilized $\alpha$-amylase

To know the optimum temperature of the native and immobilized enzyme was performed by varying the temperature at $55,60,65,70,75.80$ and $85^{\circ} \mathrm{C}$ for 30 minutes. The residual activities $(\%)$ of the native and immobilized enzyme were then evaluated and compared using Mandels method ${ }^{19}$.

\subsubsection{The thermal stability test of native and immobilized $\alpha$-amylase}

The stability of enzymes was done by measuring the residual activity of the enzyme after being incubated for $0,10,20,30,40,50,60,70$, and 80 minutes at a temperature of $65^{\circ} \mathrm{C}^{22}$.

\subsubsection{Determination of half-life $\left(t^{1} / 2\right)$,} inactivation rate constant $\left(k_{i}\right)$ and denaturation energy change $\left(\Delta \mathbf{G}_{\mathbf{i}}\right)$

Determination of $k_{i}$ and $t_{1} / 2$ value is based on the first order of inactivation kinetics equation between residual enzyme activity at $t_{0}\left([E]_{0}\right)$ and residual activity at $\mathrm{t}_{\mathrm{i}}\left([\mathrm{E}]_{\mathrm{i}}\right)^{23}$ :

$\ln \frac{[\mathrm{E}]_{\mathrm{i}}}{[\mathrm{E}]_{\mathrm{o}}}=-\mathrm{k}_{\mathrm{i}} \cdot \mathrm{t}_{1 / 2}$

The $\Delta \mathrm{Gi}$ of the enzymes was performed using the derivative of the thermodynamic equation (Equation 2) ${ }^{23}$ :

$\Delta \mathrm{G}_{\mathrm{i}}=-\mathrm{RT} \ln \frac{\mathrm{k}_{\mathrm{i}} \cdot \mathrm{h}}{\mathrm{k}_{\mathrm{B}} \cdot \mathrm{T}}$ 


\subsubsection{Determination of kinetics data of immobilized enzyme}

The values of $\mathrm{K}_{\mathrm{m}}$ constant and $\mathrm{V}_{\max }$ of native enzyme determined from Lineweaver-Burk by varying the substrate concentration (amylum solution) $0.1 ; 0.2 ; 0.4 ; 0.6 ; 0.8 ; 1 \%$ at $65^{\circ} \mathrm{C}$ for 30 minutes. The correlation data between the enzyme rate reaction against substrate concentration was plotted to Lineweaver-Burk graph.

\subsubsection{Reusability of immobilized enzyme}

The immobilized enzyme which has been used (reacted with substrate) washed with a phosphate buffer with optimum $\mathrm{pH}$ then centrifugated. The precipitate of immobilized enzyme reacted with a new substrate, then followed by testing and comparing the residual activity (\%) of the immobilized enzyme before and after the repeated use using Mandels method ${ }^{19}$.

\section{Results and Discussion}

\subsection{Immobilization of purified enzyme}

3.1.1. Determination of optimal glutaraldehyde concentration

The results of optimal glutaraldehyde binding are shown in Fig. 1 Maximum activity $(1.31 \mathrm{U} / \mathrm{mL})$ was observed at $0.4 \%$ glutaraldehyde.

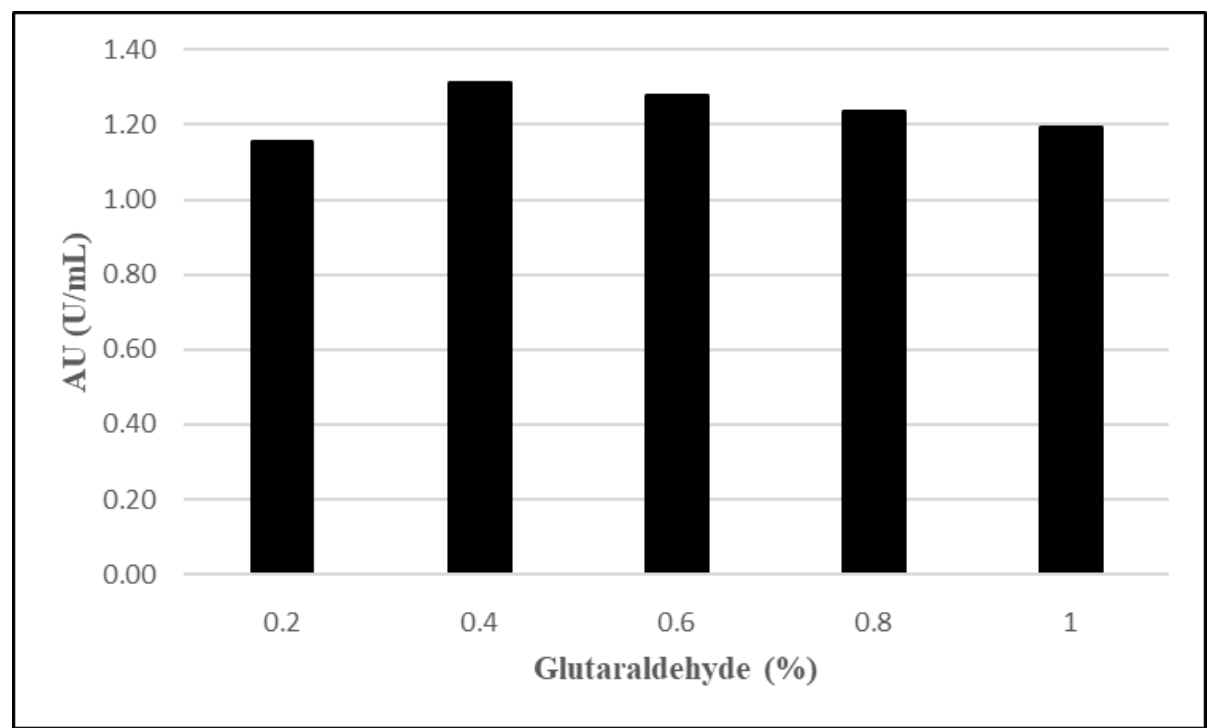

Figure 1. The unit activity of $\alpha$-amylase at various concentrations of added glutaraldehyde

\subsubsection{Determination of optimal pH binding}

Fig.2 shows that the highest unit activity of immobilized $\alpha$-amylase on chitosan matrix was at $\mathrm{pH} 7.0$, namely $1.805 \mathrm{U} / \mathrm{mL}$. It was also found that under acidic condition, the matrix was in gel form, thus the affinity binding of the matrix towards the enzyme getting low.

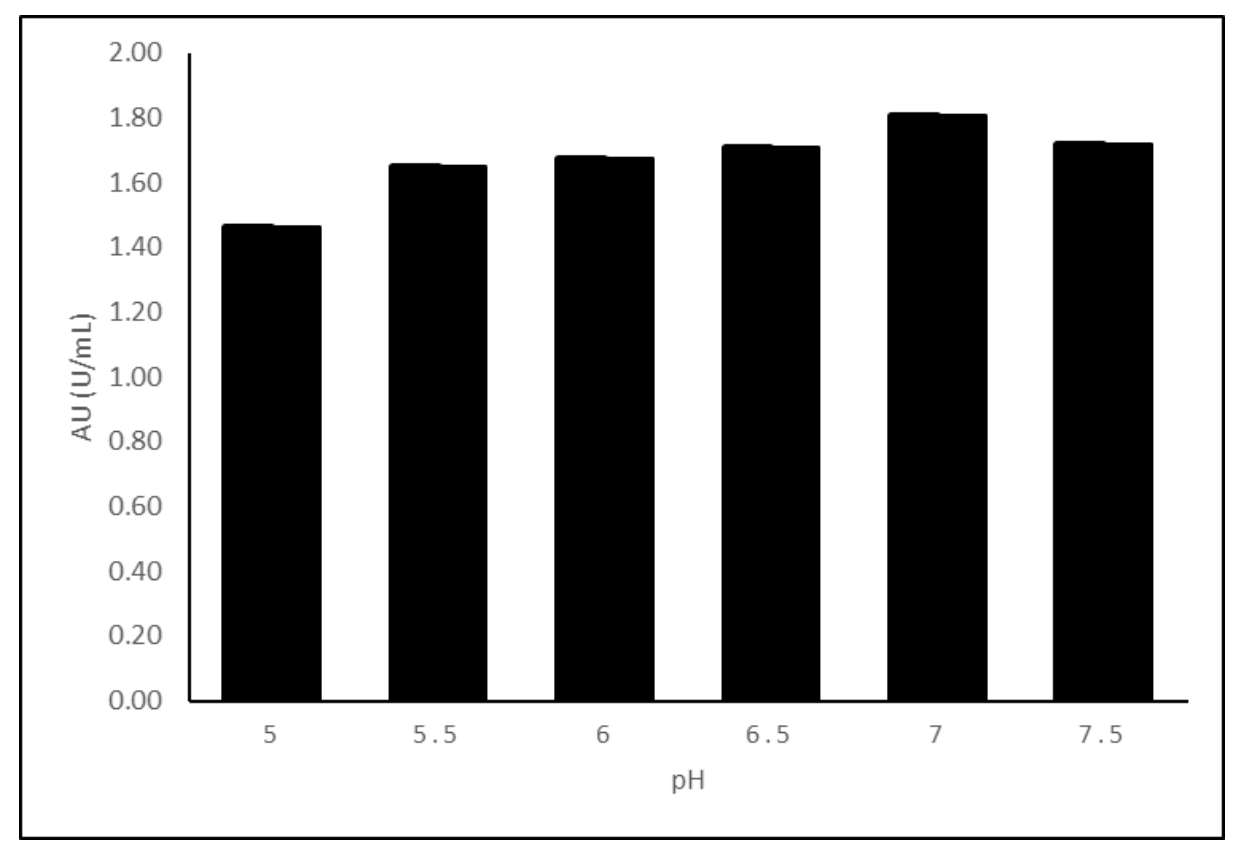

Figure 2. Unit activity of $\alpha$-amylase at various binding $\mathrm{pH}$ with chitosan matrix 


\subsection{Characterization of native and immobilized o-amylase}

\subsubsection{Determination of optimum temperature}

Fig.3 shows that the optimum temperature of the native enzyme was $65^{\circ} \mathrm{C}$, while the immobilized enzyme has an optimum temperature higher i.e. at $75^{\circ} \mathrm{C}$. This indicated that the immobilized enzyme can work at a higher temperature than the native enzyme to convert the substrate to the products. The temperature shift was due to the steric hindrance of the chitosan to the enzyme molecule, so the enzyme was guarded against the effect of denaturation because of heat ${ }^{24}$.

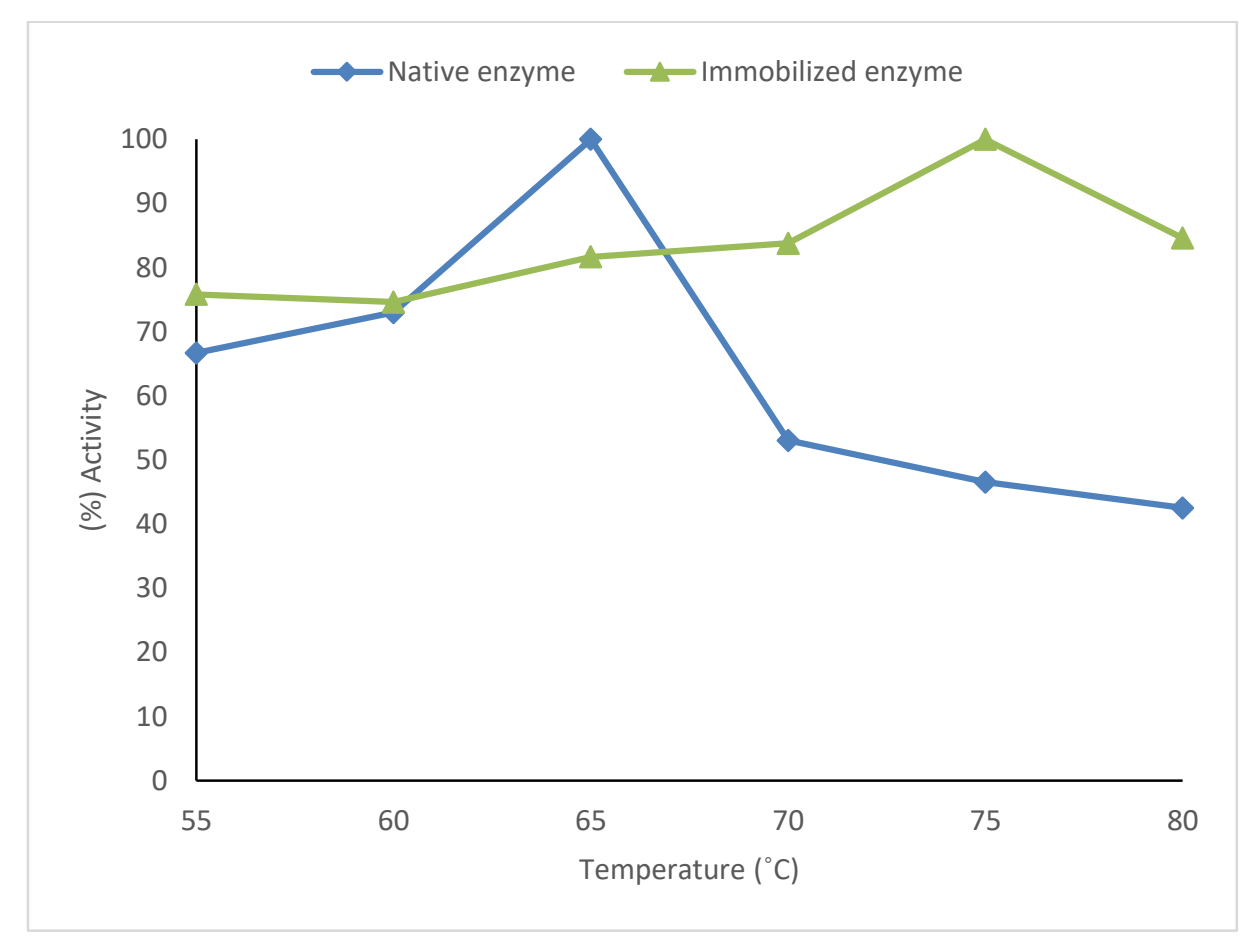

Figure 3. The optimum temperature of native and immobilized enzyme

\subsubsection{The stability test of immobilized enzyme}

Fig.4 shows that the native enzyme has (\%) residual activity lower than the immobilized enzyme. The residual activity of the native enzyme after incubating for $80 \mathrm{~min}$ was $58 \%$, while the immobilized enzyme was $86.15 \%$. This is because the immobilized enzyme protected by the immobile matrix from the effect of extreme temperature, so the immobilized enzyme becomes more stable.

It can be said that the immobilized enzyme has higher stability than the native enzyme $22,24,25$.

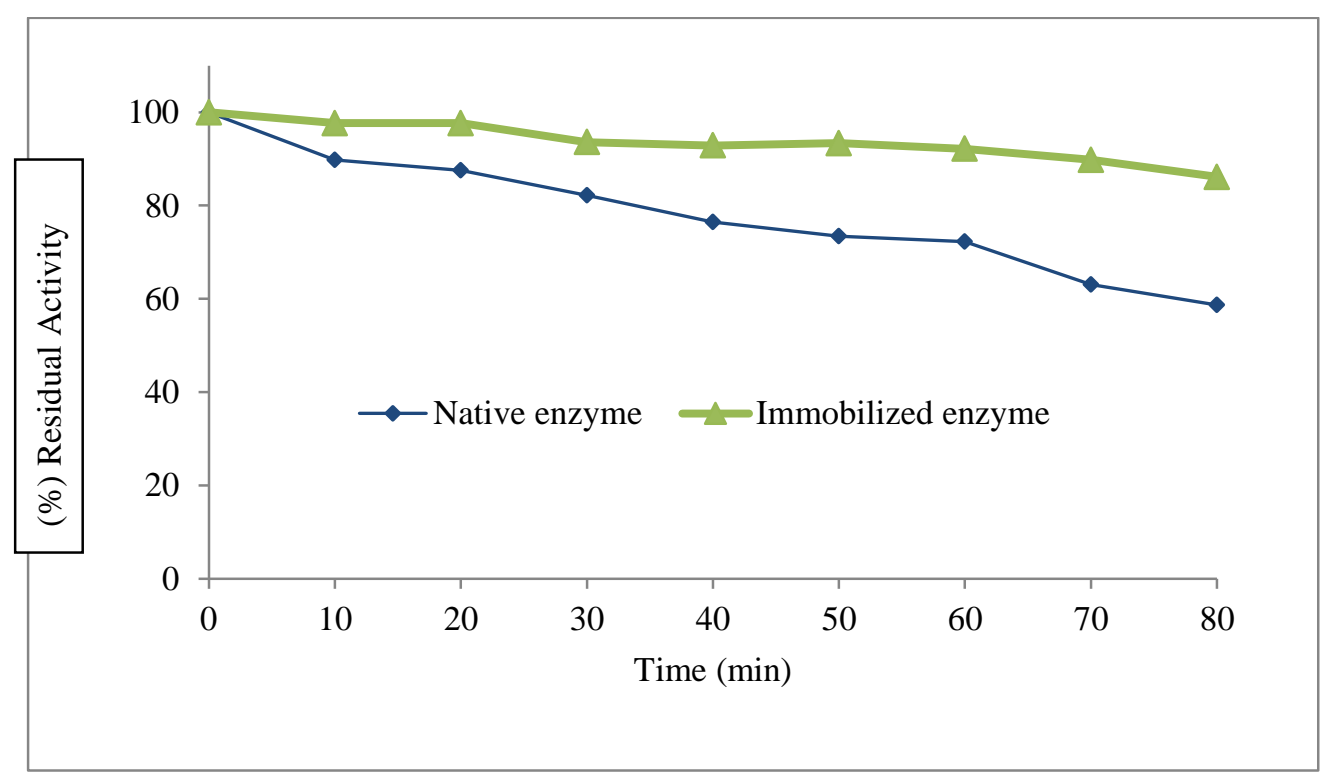

Figure 4. The thermal stability of native and immobilized enzyme 
3.2.3. Determination of half-life $\left(t_{1 / 2}\right)$, inactivation rate constant $\left(k_{i}\right)$, and energy change due to denaturation $\left(\Delta \mathbf{G}_{\mathbf{i}}\right)$

The values of $\mathrm{t}_{1 / 2}, \mathrm{k}_{\mathrm{i}}$, and $\Delta \mathrm{G}_{\mathrm{i}}$ of the native and immobilized enzyme can be seen in Table 1. Based on Table 1 , it is known that the $t_{1} / 2$ of the immobilized enzyme has increased 3.8 times compared to the native enzyme. The time change was 113.61 minutes to 433.13 minutes. The decrease of inactivation rate constant $\left(\mathrm{k}_{\mathrm{i}}\right)$ on the immobilized enzyme is an indication of the decrease of denaturation rate of the enzyme. The decrease of $\mathrm{k}_{\mathrm{i}}$ value is predicted because the condition of the enzyme is less flexible in water, so the unfolding of the enzyme is decreased and the stability of the enzyme has increased ${ }^{22,24}$.

Table 1. Values of $k_{i}, \Delta G_{i}$, and $t_{1 / 2}$ of native and immobilized enzyme.

\begin{tabular}{|c|c|c|c|c|}
\hline Enzyme & $\begin{array}{c}\mathbf{k}_{\mathbf{i}} \\
\left(\mathbf{m i n}^{-\mathbf{1}}\right)\end{array}$ & $\begin{array}{c}\Delta \mathbf{G}_{\mathbf{i}} \\
\left(\mathbf{k J} \mathbf{~ m o l}^{-\mathbf{1}}\right)\end{array}$ & $\begin{array}{c}\mathbf{t} / \mathbf{2} \\
(\mathbf{m i n})\end{array}$ & Increase \\
\hline Native & 0.0061 & 107.34 & 113.61 & 1 \\
\hline Immobilized & 0.0016 & 111.06 & 433.13 & 3.8 \\
\hline
\end{tabular}

The increase of $\Delta G_{i}$ value of the immobilized enzyme indicating that the structural conformation of the enzyme becomes more folding than the initial condition causing the enzyme structure is more rigid and less flexible in water, so the energy required to denature enzyme is higher (Table 1$)^{22,24,25}$. The more rigid of the enzyme structure has a stronger bond; thus the enzyme conformation is not easily opened, and the tertiary structure of the enzyme can be maintaned. Based on the decrease of $k_{i}$ value, the increase of $\Delta \mathrm{G}_{\mathrm{i}}$ and $\mathrm{t}_{1 / 2}$ values, it is known that immobilization using chitosan has successfully increased the stability of the enzyme.

\subsubsection{Determination of kinetic data of immobilized enzyme}

The $\mathrm{K}_{\mathrm{M}}$ and Vmax values were determined using the graph of Lineweaver-Burk equation (Fig.5). Based on Fig.5, the reaction rate of the enzyme increasing with the increase of substrate concentration. If the substrate concentration is increased, more substrate will interact with the enzyme, so the complex of enzyme-substrate formed will also increase; as a result, the formation of the product will also increase. The values of $\mathrm{K}_{\mathrm{M}}$ and $\mathrm{V}_{\max }$ of native and immobilized $\alpha$-amylase can be seen in Table 2 .

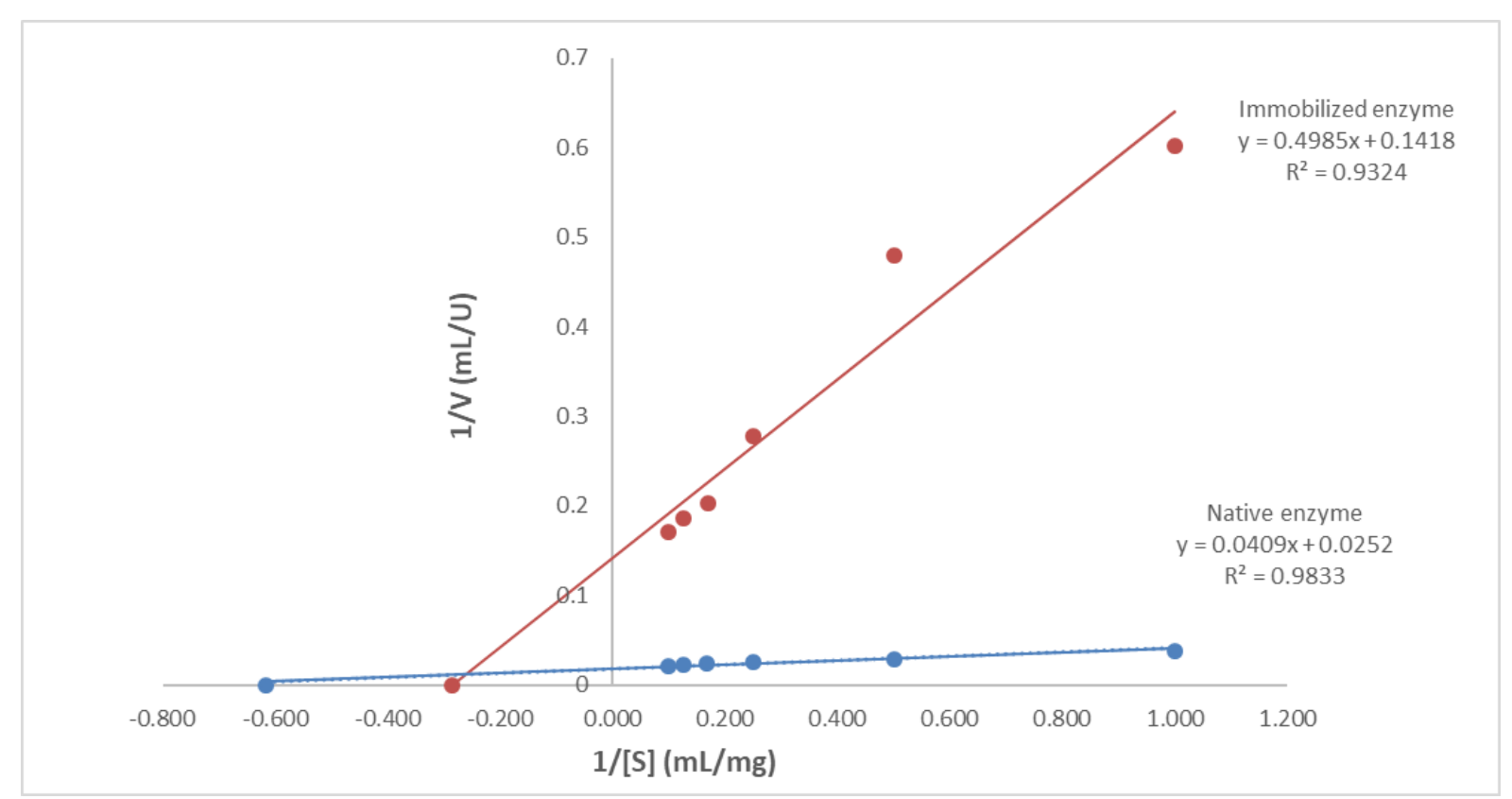

Figure 5. Lineweaver-Burk graph of native and immobilized enzyme

Table 2. values of $K_{M}$ and $V_{\max }$ of native and immobilized $\alpha$-amylase.

\begin{tabular}{|c|c|c|}
\hline Enzyme & $\begin{array}{c}V_{\max } \\
\left(\mu \mathrm{mol} \mathrm{mL}^{-1} \mathrm{~min}^{-1}\right)\end{array}$ & $\begin{array}{c}\mathbf{K}_{M} \\
\left(\mathrm{mg} \mathrm{mL}^{-1} \text { substrate }\right)\end{array}$ \\
\hline Native & 39.68 & 1.63 \\
\hline Immobilized & 7.05 & 3.514 \\
\hline
\end{tabular}


The increase of $\mathrm{K}_{\mathrm{M}}$ value on immobilized enzyme indicated that the affinity immobilized enzyme towards the substrate become lower, therefore, the higher substrate concentration needed to reach the maximum rate reaction or the similar rate to the native enzyme. The increase of $\mathrm{K}_{\mathrm{M}}$ value can be caused by the formation change of the enzyme due to the immobilization procedure as well as the decrease of substrate access to bind with the active site of the immobilized enzyme ${ }^{21}$.

$\mathrm{V}_{\max }$ is a maximum rate limit of an enzyme; an enzyme is saturated because of the substrate and is no longer functional. The decrease of $\mathrm{V}_{\max }$ value on the immobilized enzyme indicated that the maximum rate of the immobilized enzyme has decreased due to the formation change of enzyme after immobilization. The addition of glutaraldehyde in the immobilization can decrease enzyme activity and inhibit the stacking the substrate on enzyme because of the change on enzyme structure and the decrease of substrate access to the site active of immobilized enzyme ${ }^{15}$.

\subsubsection{The Reusability of immobilized enzyme}

The relationship of reusability and residual activity (\%) of the immobilized enzyme is shown in Fig.6. Based on this Fig. 6 , the immobilized $\alpha$-amylase has reusability of 6 times. The decrease of enzyme activity after immobilization can be seen from the residual enzyme activity after the repeated use. The residual enzyme activities from the first to fifth used were $100,75,49,43,24$, and $16 \%$, respectively. After being used for six-time, the activity of immobilized enzyme has decreased with residual activity $16 \%$. The activity decrease of the immobilized enzyme after reuse perhaps caused by the release of enzyme bound to the chitosan matrix when it was washed by phosphate buffer ${ }^{26}$.

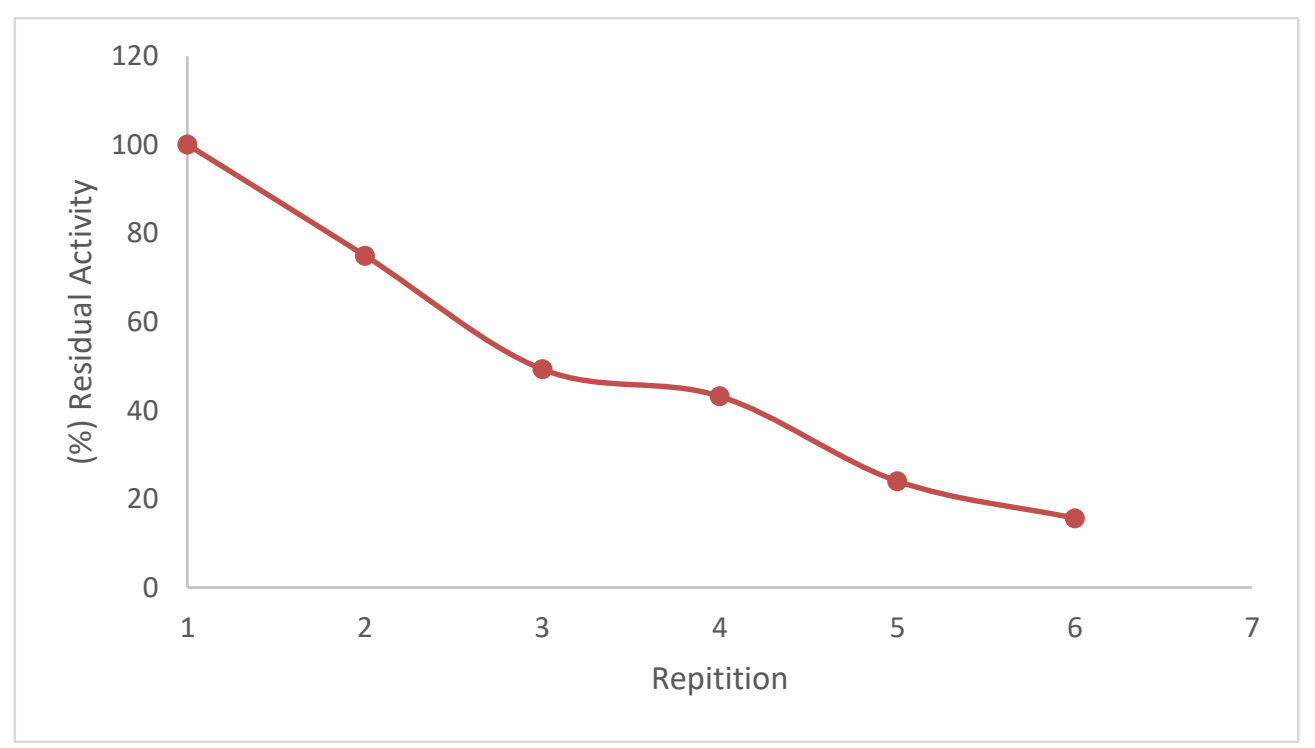

Figure 6. The reusability of immobilized $\alpha$-amylase on chitosan matrix

\section{Conclusions}

The optimum temperature of the immobilized enzyme has significantly increased from the native enzyme, i.e. an increase of $10^{\circ} \mathrm{C}$. The immobilized enzyme was able to be reused for 6 times, indicated that it is much better than the native enzyme. The immobilization of $\alpha$-amylase with chitosan has successfully increased the thermal stability of this enzyme as seen from the decrease of $\mathrm{k}_{\mathrm{i}}$, and the increase of $\Delta \mathrm{G}_{\mathrm{i}}$ and half-life $\left(\mathrm{t}_{1} / 2\right)$ values.

\section{Acknowledgement}

The authors are grateful to Directorate of Research and Community Services, The Ministry of Research, Technology and Higher Education, Indonesia. That provided fund for this project to be undertaken through Penelitian Dasar (Basic Research Grant Scheme) 2019 with contract number 065/SP2H/LT/DRPM/2019.

\section{References}

1- V. Horvathova, S. Janecek, E. Sturdik, Amylolytic enzymes: Their specificities, origins, and properties, Biologia Bratislava, 2000, 55, 605-615.

2- W. M. Fogarty, C. T. Kelly, Enzyme and Fermentation Biotechnology, Ellis Horwood Limited, West Sussex, England, 1979, pp, 45-52.

3- A. A. Simair, A. S. Qureshi, I. Khushk, C. H. Ali, S. Lashari, M. A. Bhutto, C. Lu, Production and partial characterization of $\alpha$-amylase enzyme from bacillus sp. bcc 01-50 and potential applications, BioMed Research International, 2017, 2017, 1-9.

4- S. Trabelsi, S. B. Mabrouk, M. Kriaa, R. Ameri, M. Sahnoun, M. Mezghani, S. Bejar, The optimized production, purification, characterization, and application in the breadmaking industry of three acid-stable alpha- 
amylases isoforms from a new isolated Bacillus subtilis strain US586, Journal of Food Biochemistry, 2019, 43(5), e12826.

5- A. C. Yu, J. F. Loo, S. Yu, S. K. Kong, T. F. Chan, Monitoring bacterial growth using tunable resistive pulse sensing with a porebased technique, Applied Microbiology and Biotechnology, 2014, 98, 855-862.

6- R. Singh, M. Kumar, A. Mittal, P. K. Mehta, Microbial enzymes: industrial progress in $21 \mathrm{st}$ century, Biotech, 2016, 6, 174.

7- G. Bayramoglu, M. Yilmaz, M. Y. Arica, Immobilization of a thermostable $\alpha$-amylase onto reactive membranes: kinetics characterization and application to continuous starch hydrolysis, Food Chemistry, 2004, 84, 591-599.

8- Yandri, T. Suhartati, S. Hadi, Immobilization of $\alpha$-amylase from locale bacteria isolate Bacillus subtilis ITBCCB148 with diethylaminoethyl cellulose (DEAE-Cellulose), Material Science Research India, 2010, 7, 123-128.

9- Yandri, D. Susanti, T. Suhartati, S. Hadi, Immobilization of $\alpha$-amylase from Locale Bacteria Isolate Bacillus subtilis ITBCCB148 with Carboxymethyl Cellulose (CM-Cellulose), Modern Applied Science, 2012, 6(3), 81-86.

10-Yandri, T. Suhartati, S. D. Yuwono, H. I. Qudus, E. R. Tiarsa, S. Hadi, Immobilization of $\alpha$-amylase From Bacillus subtilis ITBCCB148 Using Bentonit, Asian Journal of Microbiology, Biotechnology and Environmental Science, 2018, 20, 487-492.

11-M. E. Sedghat, M. Ghiaci, H. Aghaei, S. Soleimanian-Zad. Enzyme immobilization. Part 3 Immobilization of $\alpha$-amylase on Na-bentonite and modified bentonite, Applied Clay Science, 2009, 46, 125-130.

12-Yandri, P. Amalia, T. Suhartati, S. Hadi, Effect of immobilization towards thermal stability of $\alpha$-amylase isolated from locale bacteria isolate Bacillus subtilis ITBCCB148 with calcium alginate, Asian Journal of Chemistry, 2013, 25 , 6897-6899.

13-P. Tripathi, A. Kumari, P. Rath, A. M. Kayastha, Immobilization of $\alpha$-amylase from mung beans (Vigna radiata) on Amberlite MB 150 and chitosan beads: A comparative study, Journal of Molecular Catalysis B: Enzymatic, 2007, 49, 69-74.

14-N. Jaiswal, O. Prakash, M. Talat, S. H. Hasan, $\alpha$-Amylase immobilization on gelatin: Optimization of process variables, Journal of Genetic Engineering and Biotechnology, 2012, 10, 161-167.
15-S. A. Cetinus, H. N. Oztop, Immobilization of catalase into chemically crosslinked chitosan beads, Enzyme and Microbial Technology, 2003, 32, 889-894.

16-Yandri, T. Suhartati, S. Hadi, Purification and Characterization of Extracellular $\alpha$-Amilase Enzyme from Locale Bacteria Isolate Bacillus subtilis ITBCCB148, European Journal of Scientific Research, 2010, 39, 64-67.

17-B. K. Gogoi, R. L. Bezbaruah, K. R. Pillai, J. N. Baruah, Production, purification and characterization of an $\alpha$-amylase produced by Saccharomycopsis fibuligera, Journal of Applied Biochemistry, 1987, 63, 373-379.

18-H. Fuwa, A new method for microdetermination of amylase activity by the use of amylose as the substrat, The Journal of Biochemistry, 1954, 41, 583-603.

19-M. Mandels, R. Andreotti, C. Roche, Measurement of saccarifying cellulase, Biotechnology Bioenginering, 1976, 6, 21-33.

20-O. H. Lowry, N. J. Rosebrough, A. L. Farr, R. J. Randall, Protein measurement with the Folin phenol reagent, Journal of Biological Chemistry, 1951, 193-265.

21-B. Krajewska, Application of chitin- and chitosan-based materials for enzyme immobilization: a review, Enzyme and Microbial Technology, 2004, 35, 126-139.

22-Z. Yang, D. Michael, A. Robert, X. Y. Fang, J. R. Alan, Polyethylene glycol-induced stabilization of subtilisin, Enzyme and Microbial Technology, 1996, 18, 82-89.

23-D. Kazan, H. Ertan, A. Erarslan, Stabilization of Escherichia coli Penicillin G acylase against thermal inactivation by cross-linking with dextran dialdehyde polymers, Applied Microbiology and Biotechnology, 1997, 48, 191-197.

24-M. Y. Chang, R. S. Juang, Activities, stabilities and reaction kinetics of three free and chitosanclay composite immobilized enzymes, Enzyme and Microbial Technology, 2004, 36, 75-82.

25-S. Stahl, Thermophilic microorganisms: The biological background for thermophily and thermoresistance of enzymes in Thermostability of Enzymes (Gupta, M.N. editor), Springer Verlag, New Delhi, 1999, pp. 59-60.

26-M. T. Xavier, V. F. Soares, D. G. Freire, C. P. Moreira, M. F. Mendes, E. Bon, $\alpha$-Amylase and glucoamylase immobilized on chitin and ceramic supports, Biomass, 1987, 13, 25-32. 